\title{
Effects of Cocaine on c-Fos and NGFI-B mRNA Expression in Transgenic Mice Underexpressing Glucocorticoid Receptors
}

\author{
M St-Hilaire', P-O Tremblay', D Lévesque ${ }^{1,2}$, N Barden ${ }^{1,3}$ and C Rouillard*,1,2 \\ 'Unité de Neuroscience, Centre de recherche du CHUL, Sainte-Foy, Québec, Canada; ²Département de Médecine, Université Laval, Sainte-Foy, \\ Québec, Canada; ${ }^{3}$ Département d'anatomie-Physiologie, Université Laval, Sainte-Foy, Québec, Canada
}

\begin{abstract}
Numerous evidences suggest that stress and stress-related hormones can modulate the activity of the brain reward pathway and thus may account for individual vulnerability towards the reinforcing effects of drugs of abuse. Transgenic (TG) mice expressing an antisense mRNA against the glucocorticoid receptor (GR), which partially blocks GR expression, were used to assess the role of GR dysfunction on cocaine (COC)-induced c-fos and Nerve-Growth Factor Inducible-B (NGFI-B, or Nur77) gene expression. These two genes belong to different families of transcription factors and have been shown to be modulated by various dopaminergic drugs. TG and wild-type (WT) mice were both acutely and repeatedly treated with $\operatorname{COC}(20 \mathrm{mg} / \mathrm{kg}$, i.p.). In the chronic experiment, mice received a 5-day treatment of $\mathrm{COC}$ and were challenged 5 days later with $\mathrm{COC}$ or vehicle. Locomotor activity was assessed during the entire chronic experiment in the mouse home cages. Animals were sacrificed I h after the last injection and NGFI-B and c-fos mRNA levels in the prefrontal cortex the nucleus accumbens and the striatum were measured by in situ hybridization. Acute COC administration led to significantly smaller c-fos increases in TG mice compared to WT, whereas repeated COC treatment potentiated c-fos induction both in TG and WT mice to equivalent levels. TG mice displayed higher basal NGFI-B expression in the nucleus accumbens and the level of NGFI-B mRNA was differently modulated by COC in TG mice compared to WT mice. In accordance with data on c-fos expression, behavioral data indicate a blunted locomotor effect on the first COC injection in TG mice, a phenomenon corrected by the repeated COC treatment. These results suggest that an alteration of the hypothalamus-pituitary-adrenal axis can modify COC-induced regulation of the transcription factors c-fos and NGFI-B, and that these changes parallel those seen at the behavioral level. It also demonstrates that the differences at the behavioral and molecular levels noted between TG and WT mice after acute COC injection disappear following repeated COC administration, suggesting that repeated $\mathrm{COC}$ has a greater impact in TG mice underexpressing GRs.

Neuropsychopharmacology (2003) 28, 478-489. doi: I0.1 038/s..npp. 1300067
\end{abstract}

Keywords: transgenic mice; glucocorticoids; in situ hybridization; transcription factors; nuclear receptors

In some individuals repeated cocaine (COC) exposure will lead to addiction, a pathological state characterized by a compulsive drug-seeking and drug-taking behavior. It is thought that genetic predisposition as well as environmental factors could shape an individual vulnerability towards the reinforcing properties of drugs of abuse. Although the exact mechanisms implicated in this phenomenon are still unclear, data in the literature suggest a role for stress and the hypothalamus-pituitary-adrenal (HPA) axis (Piazza et $a l, 1996 a)$. For example, it has been shown that stressful events can facilitate the acquisition, maintenance, and relapse of drug self-administration (Piazza and Le Moal,

*Correspondence: C Rouillard, Unité de Neuroscience RC-9800, Centre de recherche du CHUQ (pavillon CHUL), 2705 Boul. Laurier, Sainte-Foy, Québec, Canada GIV 4G2, Tel: + I 4 I 8654 2152, Fax: + I 4I8 654 2753, E-mail: claude.rouillard@crchul.ulaval.ca

Received 12 February 2002; revised 8 July 2002; accepted 9 September 2002

Online publication: 19 September 2002 at http://www/acnp.org/ citations/Npp091902384
1998; Shaham et al, 2000). It has also been demonstrated that chronic stress exposure potentiates COC-induced locomotor activity (Haile et al, 2001). There is numerous evidence that stress hormones can modulate dopaminergic function in the mesolimbic pathway. Corticosterone administration has been shown to increase basal release of dopamine (DA) in the nucleus accumbens (Piazza et al, 1996b), whereas adrenalectomy reduces basal extracellular DA levels and blunts COC-induced DA increase in the same brain structure (Barrot et al, 2000). Evidence of a direct interaction between mesolimbic DAergic system and the HPA axis is further emphasized by the fact that glucocorticoid receptors (GRs) are expressed by DAergic neurons (Harfstrand et al, 1986) and that a glucocorticoid-responsive element (GRE) is found in the promoter region of the mouse tyrosine hydroxylase gene (Hagerty et al, 2001a, b).

Transgenic (TG) mice bearing a transgene coding for a GR antisense RNA (Pepin et al, 1992), which partially blocks GR expression, have been previously used to investigate the consequence of impaired functioning of the GR on various 
behavioral (Spanagel et al, 1996; Rochford et al, 1997; Sillaber et al, 1998), neuroendocrine (Beaulieu et al, 1994; Stec et al, 1994) and neurochemical responses (Farisse et al, 2000; Linthorst et al, 2000). These mice present an approximate $30-50 \%$ reduction in GR mRNA levels in the brain (Pepin et al, 1992) and a 10-fold higher dose of dexamethasone is needed to suppress their circulating corticosterone levels when compared to normal mice (Barden et al, 1997). Of particular interest, these TG mice display higher locomotive activity when placed in a novel environment (Beaulieu et al, 1994), a characteristic hypothesized to predict an increased sensitivity towards the reinforcing effects of drugs of abuse (Piazza et al, 1989; Hooks et al, 1991). In addition, this TG mouse model shows a stronger locomotive response than control following an acute injection of amphetamine (Cyr et al, 2001).

Addiction is thought to rely on plastic neuronal adaptation initiated in the mesolimbic system by repeated administration of drugs of abuse (Hyman and Malenka, 2001; Nestler, 2001). Regulation of gene expression is one putative mechanism through which COC could initiate persistent neural and behavioral changes and in this way, transcription factors may play a crucial role. Levels of some transcription factors appear to increase in the central nervous system in response to acute and chronic COC administration (Young et al, 1991; Hope et al, 1992, 1994). Among the transcription factors studied so far, Fos members of the immediate-early gene family (c-fos, Fosrelated antigens (FRAs) and $\Delta$ FosB) have been intensively investigated (Nestler, 2001). Nerve Growth Factor inducibleB (NGFI-B, also known as Nur77) is another transcription factor, which is closely associated with DA systems in the brain. This orphan ligand-activated nuclear receptor belongs to the steroid/thyroid hormone receptor family and is constitutively expressed in target structures of DA systems (Zetterström et al, 1996). NGFI-B mRNA expression can be modulated by DA and serotoninergic drugs (Gervais et al, 1999). Furthermore, typical and atypical antipsychotic drugs induce contrasting patterns of NGFI-B expression after acute and chronic administration (Beaudry et al, 2000; Langlois et al, 2001). Of particular interest, other drugs of abuse such as morphine have been shown to modulate NGFI-B expression in the mesolimbic system (Werme et al, 2000a).

The aim of the present study was to assess the influence of GR dysfunction on COC-induced transcription factor mRNA expression in target structures of DA systems. We studied and compared the modulation of c-fos and NGFI-B, which belong to two families of transcription factors, after an acute COC injection, as well as in a paradigm of COC sensitization, in normal and TG mice underexpressing GRs. We also established a parallel between COC-induced gene expression and behavioral activity.

\section{EXPERIMENTAL PROCEDURES}

\section{Animals and Treatments}

Adult male wild-type (WT) $\mathrm{B}_{6} \mathrm{C}_{3} \mathrm{~F}_{1}$ mice (Charles River; StConstant, Québec, Canada) and male homozygous TG mice underexpressing GRs were used. The TG mice bearing the glucocorticoid antisense construct (an inverted $1.815 \mathrm{~kb}$ fragment of the $3^{\prime}$ noncoding region of the GR coupled to a $2.3 \mathrm{~kb}$ EcoR1/HindIII human neurofilament gene promoter inserted in the genome of $\mathrm{WT}_{6} \mathrm{C}_{3} \mathrm{~F}_{1}$ mice (Pepin et al, 1992)) were bred as homozygotes in our laboratory. Animals were kept in groups of five per cage and maintained in a standard $12 \mathrm{~h}$ dark/light cycle (lights on 08:00) with food and water available ad libidum. All experiments were conducted during the light portion of the cycle. At the time of killing, animals were about 8 weeks old. Handling of mice was performed in accordance with the Canadian Guide for The Care and Use of Laboratory Animals. All procedures were approved by the Institutional Animal Care Committee of Laval University and all efforts were made to minimize the number of animals used and their suffering.

In a first series of experiments, $\mathrm{WT}$ and TG mice received a single injection of either the vehicle $(\mathrm{NaCl} 0.9 \%$, i.p.) or COC $(20 \mathrm{mg} / \mathrm{kg}$, i.p.). Four groups were formed: WT/vehicle $(n=4), \mathrm{WT} / \mathrm{COC}(n=4)$, TG/vehicle $(n=6)$, and TG/COC $(n=6)$. Injections occurred between 9:00 and 9:30 am. One hour following the injection animals were decapitated and their brains were frozen on dry ice before further processing. In the second series of experiments, four different groups of mice received a COC injection $(20 \mathrm{mg} /$ $\mathrm{kg}$, i.p.) once a day for 5 days. Following the fifth administration on day 5, animals were left without treatment for 5 days. After this withdrawal period (on day $10)$, two groups of mice received the vehicle $(\mathrm{NaCl} 0.9 \%$, i.p.) (WT/vehicle $(n=4)$ and TG/vehicle $(n=4))$, whereas the other two groups received a COC challenge $(20 \mathrm{mg} / \mathrm{kg}$, i.p.) (WT/COC $(n=5)$ and TG/COC $(n=4))$. This injection pattern has been shown to lead to the development of behavioral sensitization (Partridge and Schenk, 1999). All mice were decapitated, as indicated above, $1 \mathrm{~h}$ following the last drug injection.

\section{Locomotor Activity}

Locomotor activity was recorded continuously during the repeated COC treatment using telemetry (Data Sciences International, St Paul, MN, USA). We used this system to monitor locomotion before and after each injection, and that in the mouse home cages. The system included 17 wireless receivers (TA11-TA-C20) placed under each cage and getting signals from a biocompatible transmitter implant (RA1010) introduced into each mouse. Signals from the wireless receivers were sent to a computer via a consolidation matrix (BCM100) and data acquisition was ensured by a dedicated software (Dataquest A.R.T., version 2.0). Locomotion data were analyzed for $20 \mathrm{~s}$ every $10 \mathrm{~min}$. Locomotion is expressed in locomotor counts and are based on the intensity of the signal received from the transmitter (for a detailed explanation of locomotor count calculation, see Clement et al, 1989). Results for each individual stem from an average of locomotor counts during 30-min periods (three locomotion data/30 min). For every injection during the repeated treatment with $\mathrm{COC}$, locomotion data were computed for four succeeding blocks of $30 \mathrm{~min}$, the first one being the one before the injection $(-30-0,0-30,30-60$, 60-90 $\mathrm{min})$. 


\section{Transmitter Implantation}

Transmitters $\left(2.5 \mathrm{~g} ; 1.4 \mathrm{~cm}^{2}\right)$ were introduced into the mouse peritoneal cavity. Surgery was performed under isoflurane anesthesia (isoflurane $1.5 \% ; \mathrm{O}_{2} 0.8 \mathrm{l} / \mathrm{min}$ ) (Zeneca Pharma, Canada). Experiment involving repeated COC administration began 2 weeks after transmitter implantation, thus ensuring full recovery from the surgery.

\section{In Situ Hybridization}

After having been removed from the skull and frozen on dry ice, brains were cut into $12 \mu \mathrm{m}$-thick coronal sections with a cryostat, thaw-mounted on slides and kept at $-80^{\circ} \mathrm{C}$ until further processing. Adjacent brain sections were hybridized with $c$-fos and NGFI-B probes. The antisense cRNA probe for c-fos was prepared from a $1.8 \mathrm{~kb}$ EcoRI fragment of a full-length rat $c$-fos cDNA subcloned into pBluescript SK-1 and linearized with SmaI. The antisense cRNA probe for NGFI-B stem from a $2.4 \mathrm{~kb} E c o$ RI fragment of a full-length rat NGFI-B cDNA subcloned into pBluescript SK-1 and linearized with BamHI. The single-stranded riboprobe complementary to the RNA of interest was synthesized and labeled using Promega riboprobe kit (Promega, Madison, WI), ${ }^{35}$ S]UTP (Perkin-Elmer Inc., Canada), and the RNA polymerase T3 and T7 for NGFI-B and c-fos, respectively.

The hybridization technique was performed as previously described (Beaudry et al, 2000; Langlois et al, 2001). Briefly, brain sections were fixed in a 20 -min paraformaldehyde bath (4\% paraformaldehyde in $100 \mathrm{mM}$ phosphate buffer) and then rinsed twice in phosphate buffer $(100 \mathrm{mM})$ for $5 \mathrm{~min}$. Subsequently, a triethanolamine incubation (TEA $100 \mathrm{mM}, \mathrm{pH}: 8.0)$ and a $10-\mathrm{min}$ acetylation bath $(0.25 \%$ acetic anhydride, TEA $100 \mathrm{mM}$ ) followed. Slides were finally rinsed in standard saline citrate (SSC) $(\mathrm{NaCl} 300 \mathrm{mM}$, sodium citrate $30 \mathrm{mM}$ ) and dehydrated in increasing concentrations of ethanol. The ${ }^{35} \mathrm{~S}$-labeled riboprobe was added to a concentration of $1 \times 10^{7} \mathrm{cpm} / \mathrm{ml}$ in a hybridization mix (Denhart's solution, dextran sulfate and $50 \%$ deionized formamide) and heated at $65^{\circ} \mathrm{C}$ for $5 \mathrm{~min}$. Each slide was covered up with $100 \mu$ l of the hybridization solution and a glass coverslip placed on the slide. The hybridization took place overnight at $58^{\circ} \mathrm{C}$ on a slide warmer. After hybridization, slides were soaked in SSC $(\mathrm{NaCl} 600 \mathrm{mM}$, sodium citrate $30 \mathrm{mM}$ ) for $30 \mathrm{~min}$ to remove coverslips and then washed in four subsequent SSC baths. Afterwards, slides spent $30 \mathrm{~min}$ in a $37^{\circ} \mathrm{C}$ incubation buffer with RNAse A $(2 \mathrm{mg} / 100 \mathrm{ml})$. A series of SSC baths with dithiothreitol (1 mM) follows, one of which being at $55^{\circ} \mathrm{C}$ for $30 \mathrm{~min}$. Finally, tissues were dehydrated in ethanol, dried up, and apposed to a Biomax MR film (Kodak). Autoradiograms were developed approximately $48 \mathrm{~h}$ later.

\section{Autoradiogram Quantification}

Levels of radioautographic labeling on films were quantified by computerized densitometry. Digitized brain images were obtained with a CCD camera model XC-77 (Sony) equipped with a $60 \mathrm{~mm} / 2.8 \mathrm{D}$ (Nikon) magnification lens. Images were analyzed on a MacIntosh computer using the Image
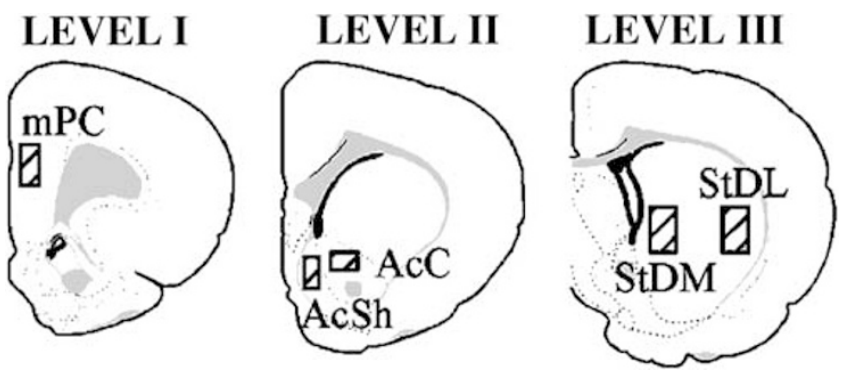

Figure I Schematic representation of the mouse forebrain regions selected for quantitative analysis of c-fos and NGFI-B mRNA expression. Levels I-III correspond to bregma 1.96, I.I8, and 0.5 levels, respectively. Specific brain areas sampled are shown as hatched boxes. AcC, nucleus accumbens core; AcSh, nucleus accumbens shell; mPC, medial prefrontal cortex; StDM, dorsomedial striatum; StDL, dorsolateral striatum.

software (Image 1.61, W Rasband, NIH). Optical density of the autoradiograms was translated in $\mu \mathrm{Ci} / \mathrm{g}$ of tissue using $\left[{ }^{14} \mathrm{C}\right]$ radioactivity standards (ARC $146 \mathrm{~A}-{ }^{14} \mathrm{C}$ standards, American Radiolabeled Chemicals Inc., St Louis). NGFI-B and c-fos mRNA labeling were measured in the medial prefrontal cortex (mPC), the shell (AcSh) and core (AcC) of the nucleus accumbens, and the striatum. This last structure was further subdivided into its dorsomedial (StDM) and dorsolateral (StDL) parts (Figure 1). The average level of labeling for each area was calculated from three adjacent brain sections of the same animal. Background intensity was subtracted from every measurements.

\section{Statistical Analysis}

For the in situ hybridization studies, differences between groups were assessed using a 2-factor (mice type $\times$ treatments) analysis of variance (ANOVA) and interactions between factors were further analyzed by the post hoc least significant difference (PLSD) Fisher's test. For the behavioral study, we performed ANOVA for repeated measures (mouse type $\times$ time course) and multiple comparisons between mouse type, using a PLSD Fisher's, when required. The post hoc comparisons were done at the time corresponding to the peek of the effect. If more than one comparison was needed for the same time course, a Bonferroni correction was taken into account.

\section{RESULTS}

\section{Effects of an Acute COC Injection on c-fos Expression}

Quantitative analysis of the film autoradiograms did not reveal any difference of basal c-fos expression between mouse types in control groups receiving vehicle injection (Figure 2, upper panels and Figure 3). In WT animals, a single injection of COC produced a significant increase in $c$-fos mRNA levels in all brain regions measured (Figure 3). In the nucleus accumbens, factorial ANOVA shows an effect of the treatment (AcSh, $F_{1,16}=14.749, P<0.01 ; A c C$, $\left.\mathrm{F}_{1,16}=7.264, P<0.05\right)$ along with an effect of the mouse type (AcSh, $\mathrm{F}_{1,16}=6.561, P<0.05 ; \quad$ AcC, $\mathrm{F}_{1,16}=5.850$, $P<0.05)$ and an interaction between the treatment and the mouse type in the AcSh subdivision (AcSh, 

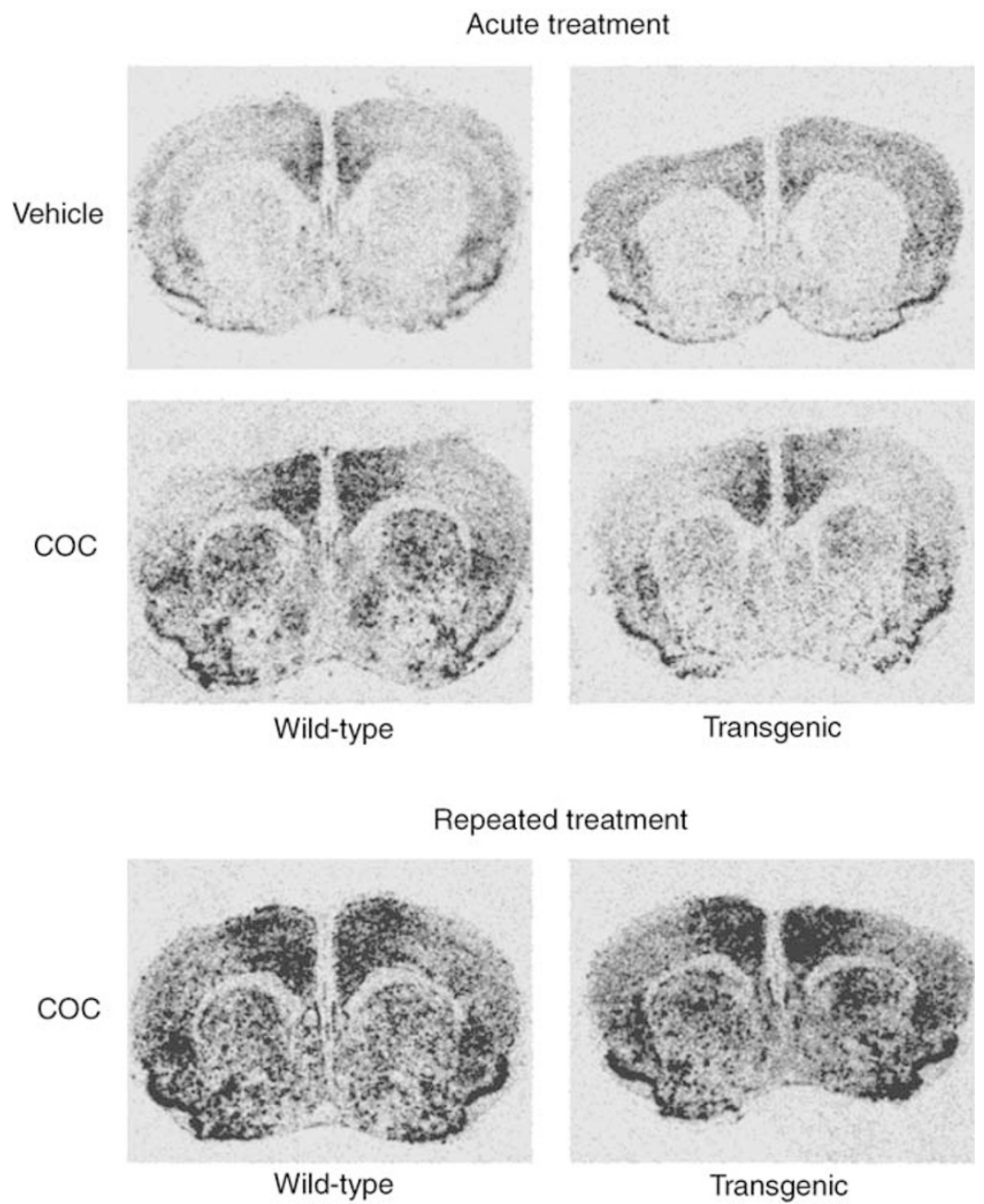

Figure 2 Representative autoradiograms showing c-fos mRNA levels radiolabeled by the $\left[{ }^{35} \mathrm{~S}\right]$-antisense riboprobe in WT and TG mice receiving vehicle (upper panels); acutely treated with COC (20 mg/kg) (middle panels) or challenged with COC following a 5-day COC pretreatment (20 mg/ $/ \mathrm{kg}$ ) and a 5-day washout period (lower panels).

$\mathrm{F}_{1,16}=14.107, P<0.01 ;$ AcC, $\left.\mathrm{F}_{1,16}=1.399, P=0.254\right)$. The post hoc test confirms that whereas the acute COC treatment increases $c$-fos mRNA levels in WT AcSh and AcC the same treatment fails to induce a significant elevation in TG mice (AcSh, $P=0.948$; AcC, $P=0.249$ ) (Figures $3 \mathrm{a}$ and $\mathrm{b}$ ). In the striatum, COC administration produced a significant upregulation of c-fos mRNA in both WT and TG mice, although the increase was significantly smaller in the TG group when compared to WT animals (Figures $3 c$ and d). For both structures, the ANOVA revealed significant differences of c-fos mRNA levels between the two mouse types (StDM, $\mathrm{F}_{1,16}=6.161, P<0.05 ; \mathrm{StDL}, \mathrm{F}_{1,16}=6.672$, $P<0.05)$, the treatment (StDM, $F_{1,16}=28.642, P<0.0001$; StDL, $\mathrm{F}_{1,16}=61.537, P<0.0001$ ), and a significative interaction between these two factors ( $\mathrm{StDM}, \mathrm{F}_{1,16}=5.595, P<0.05$; StDL, $\left.\mathrm{F}_{1,16}=8.552, P<0.01\right)$. In the mPC, the ANOVA revealed a significant effect for the treatment $\left(\mathrm{F}_{1,16}=18.203\right.$, $P<0.005)$ without any significant difference between the two mouse types $\left(\mathrm{F}_{1,16}=0.102, P=0.753\right)$ or an interaction between these factors $\left(F_{1,16}=2.016, P=0.175\right)$ (Figure 3e).

\section{Effects of a Repeated COC Treatment on c-fos Expression}

After the 5-day COC pretreatment and a subsequent 5-day weaning period, the $\mathrm{COC}$ challenge led to significant increases in c-fos mRNA levels in all regions studied and without any difference between the two mouse types when compared to vehicle control groups from the repeated condition (Figure 3). In the AcSh, the factorial ANOVA did not reveal any significant difference between the two mouse types $\left(\mathrm{F}_{1,13}=0.510, P=0.4878\right)$ nor any interaction between this factor and the treatment $\left(\mathrm{F}_{1,13}=0.444, P=0.5168\right)$ with regard to the significant effect of the COC challenge $\left(\mathrm{F}_{1,13}=24.947, \quad P<0.001\right) \quad$ (Figure 3a). The absence of difference between mouse types in c-fos mRNA expression induced by repeated COC administration is also true for the AcC (Figure 3b). Furthermore, in both the StDM and StDL, a significant increase in c-fos mRNA levels was noted following the COC challenge on day 10 (STDM, $\mathrm{F}_{1,13}=131.737, P<0.0001$; StDL, $\left.\mathrm{F}_{1,13}=50.672, P<0.0001\right)$, again without any difference between mouse types (Figures $3 \mathrm{c}$ and $\mathrm{d}$ ). In the $\mathrm{mPC}, \mathrm{COC}$ challenge increases $\mathrm{c}$-fos mRNA 

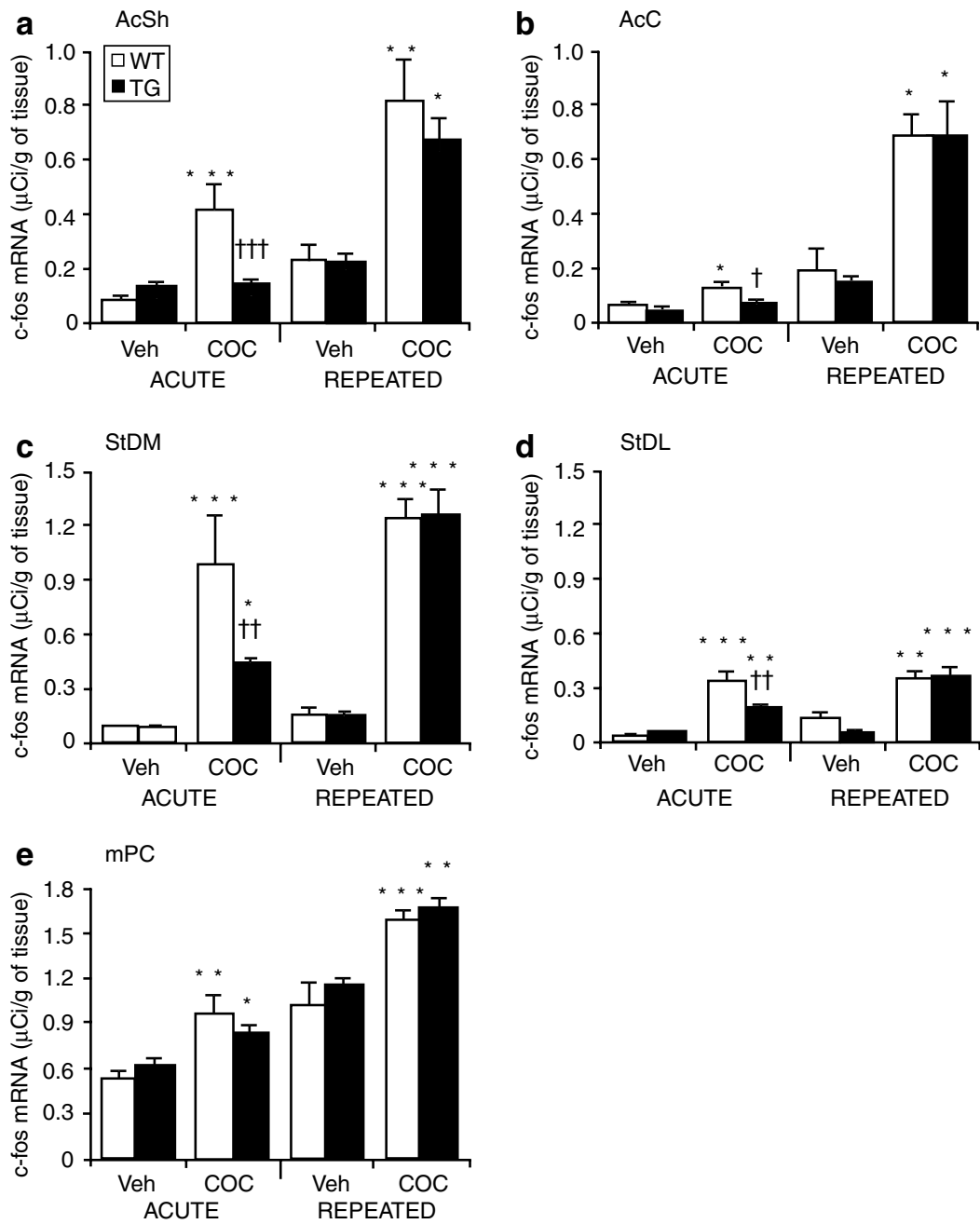

Figure 3 Histograms depicting c-fos mRNA levels after acute and repeated COC (20 mg/ $/ \mathrm{kg})$ administration. In the repeated experiment mice received vehicle or COC following a 5-day COC pretreatment $(20 \mathrm{mg} / \mathrm{kg}$ ). C-fos mRNA expression was measured in the (a) AcSh, (b) AcC, (c) StDM, (d) StDL, and (e) $\mathrm{mPC}$. Results shown represent means $\pm \mathrm{SEM}$. $* * * P<0.00 \mathrm{I}$, ** $P<0.01$, *P $<0.05$ when compared to the same mouse type receiving the vehicle administration. ${ }^{\dagger \dagger \dagger} P<0.001,{ }^{\dagger} P<0.01,{ }^{\dagger} P<0.05$ when compared to WT mice receiving the same treatment. These comparisons were done inside the same treatment, not between means from the acute and the repeated administration.

levels $\left(\mathrm{F}_{1,13}=39.743, P<0.0001\right)$ without difference between the two mouse types, here again when compared to vehicle control groups from the same condition (Figure 3e). Statistical analysis also revealed a potentiation of the effect of the COC challenge on c-fos induction when compared to the effect of an acute COC injection, and that in all structures measured without any regard to mouse types (AcSh, $\quad \mathrm{F}_{1,15}=23.146, \quad P<0.001 ; \quad$ AcC,$\quad \mathrm{F}_{1,15}=69.114$, $P<0.0001 ; \quad$ StDM, $\quad \mathrm{F}_{1,15}=13.747, \quad P<0.01 ; \quad$ StDL, $\left.\mathrm{F}_{1,15}=5.905, P<0.05 ; \mathrm{mPC}, \mathrm{F}_{1,15}=83.199, P<0.0001\right)$.

\section{Effects of an Acute COC Injection on NGFI-B Expression}

In the AcSh, significantly higher basal NGFI-B mRNA levels were observed in TG mice compared to WT (ANOVA: $\mathrm{F}_{1,16}=10.248, P<0.001$; Figure 4 upper panels and Figure $5 a)$, whereas it did not vary significantly in the other brain regions studied. In this nucleus accumbens subdivision, acute $\mathrm{COC}$ administration led to a significant downregulation of NGFI-B mRNA levels in TG mice $(P<0.05)$, whereas a nonsignificant increase was measured in WT $(P=0.0567)$ (Figure 5a). In the striatum, the levels of NGFI-B mRNA did not differ between mouse types receiving vehicle. It increased significantly in both striatal subdivisions in WT and TG mice following an acute COC injection (StDM, $\mathrm{F}_{1,16}=62.175, P<0.0001 ;$ StDL, $\left.\mathrm{F}_{1,16}=26.891, P<0.0001\right)$ (Figures $5 c$ and $d$ ). In contrast, NGFI-B mRNA levels were unaltered by an acute $\mathrm{COC}$ injection in both the $\mathrm{AcC}$ and the $\mathrm{mPC}$ ( $\mathrm{AcC}, \mathrm{F}_{1,16}=0.028, P=0.87 ; \mathrm{mPC}, \mathrm{F}_{1,16}=0.770$, $P=0.393)$. There was again no difference between $\mathrm{WT}$ and TG mice (AcC, $\mathrm{F}_{1,16}=1.403, P=0.254 ; \mathrm{mPC}, \mathrm{F}_{1,16}=0.69$, $P=0.418)$.

\section{Effects of a Repeated COC Treatment on NGFI-B Expression}

In the AcSh, the factorial ANOVA did not reveal any significant effect of the $\mathrm{COC}$ challenge $\left(\mathrm{F}_{1,13}=39.743\right.$, $P=0.5170)$, the mouse type $\left(\mathrm{F}_{1,13}=1.751, P=0.2086\right)$ nor an interaction between these factors $\left(\mathrm{F}_{1,13}=3.210\right.$, 
Acute treatment

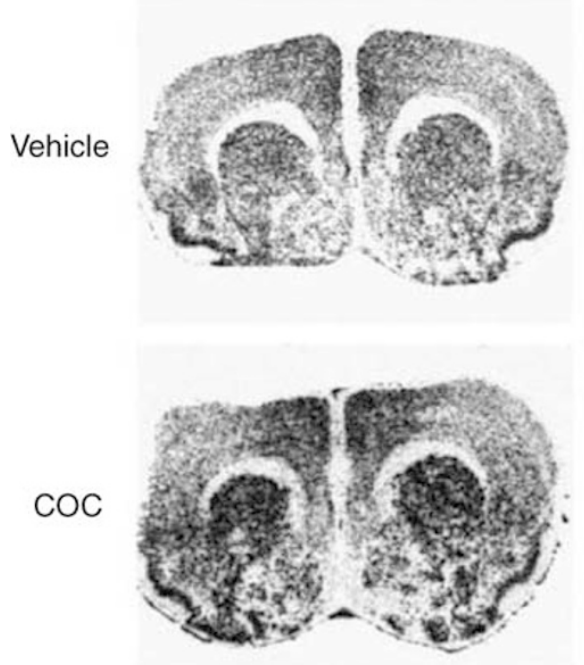

Wild-type

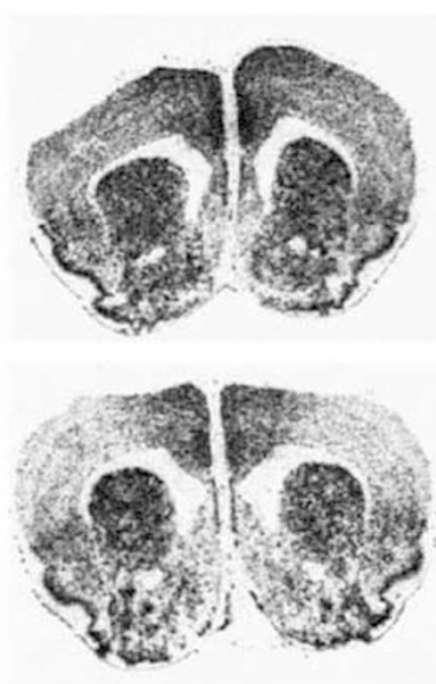

Transgenic

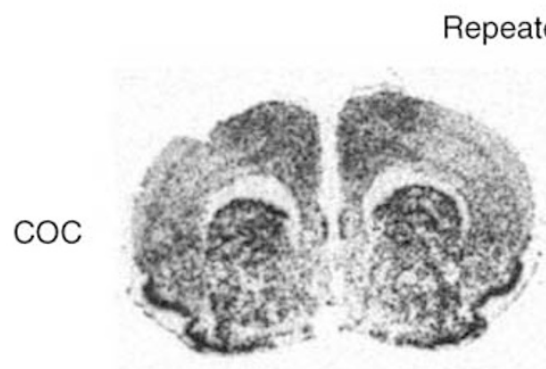

Wild-type

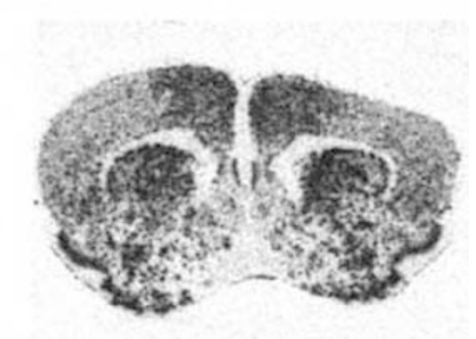

Transgenic

Figure 4 Representative autoradiograms showing NGFI-BmRNA levels radiolabeled by the $\left[{ }^{35} \mathrm{~S}\right]$-antisense riboprobe in WT and TG mice receiving the vehicle (upper panels); acutely treated with COC $(20 \mathrm{mg} / \mathrm{kg}$ ) (middle panels) or challenged with COC following a 5-day COC pretreatment $(20 \mathrm{mg} / \mathrm{kg})$ and a 5-day washout period (lower panels).

$P=0.0965)$ when comparing the groups receiving the COC challenge to their vehicle controls from the same condition (Figure 5a). Noticeably, in TG mice, repeated COC administration maintains the NGFI-B mRNA decrease seen after the acute COC injection. In the StDM, a significant effect of the treatment $\left(F_{1,13}=76.396, P<0.0001\right)$ and a difference between mouse types $\left(\mathrm{F}_{1,13}=12.642, P<0.005\right)$ were observed when analyzing means from the repeated condition (Figure $5 \mathrm{c}$ ). TG mice consistently express more NGFI-B mRNA than WT mice and COC treatment significantly upregulated NGFI-B mRNA in both mouse strains. No effects were found in the StDL nor in the mPC (Figures $5 \mathrm{~d}$ and e).

\section{Effects of COC on Locomotor Activity}

For the vehicle injection that occurred the day prior to the beginning of the repeated COC treatment, the ANOVA for repeated measures reveal an effect of the time course $\left(\mathrm{F}_{3,45}=43.683, P<0.0001\right)$, as well as a difference between the mouse types $\left(\mathrm{F}_{1,15}=4.664, P<0.05\right)$ and an interaction between these two factors $\left(F_{3,45}=7.592, P<0.001\right)$ (Figure 6a). The post hoc comparisons between periods $[-30-0]$ and $[0-30]$ showed a significant increase of locomotor response in WT animals $(P<0.0001)$, without any significant increase of locomotion in TG mice $(P=0.1482)$. On the first $\mathrm{COC}$ administration, both mouse types displayed an increased locomotor response $\left(F_{3,24}=9.367, P<0.001\right)$ (Figure 6b). This effect appeared once again blunted in TG mice as suggested by the ANOVA for repeated measures $\left(\mathrm{F}_{1,15}=4.139, P=0.06\right)$. Post hoc comparison does in fact show a significant difference between mouse type at the peak of COC-induced locomotor response $(P<0.05)$ (Figure $6 \mathrm{~b})$. Following the subsequent administration of the same COC dose, there was a potentiation of COC-induced locomotor response in TG mice. There was a significant increase in locomotor response in TG animals at the third COC injection when compared to the first one $(P<0.005)$. No significant change was observed in COC-induced locomotor response of WT animals throughout the entire repeated treatment. On the third COC administration, the ANOVA for repeated measures indicate an effect on the 

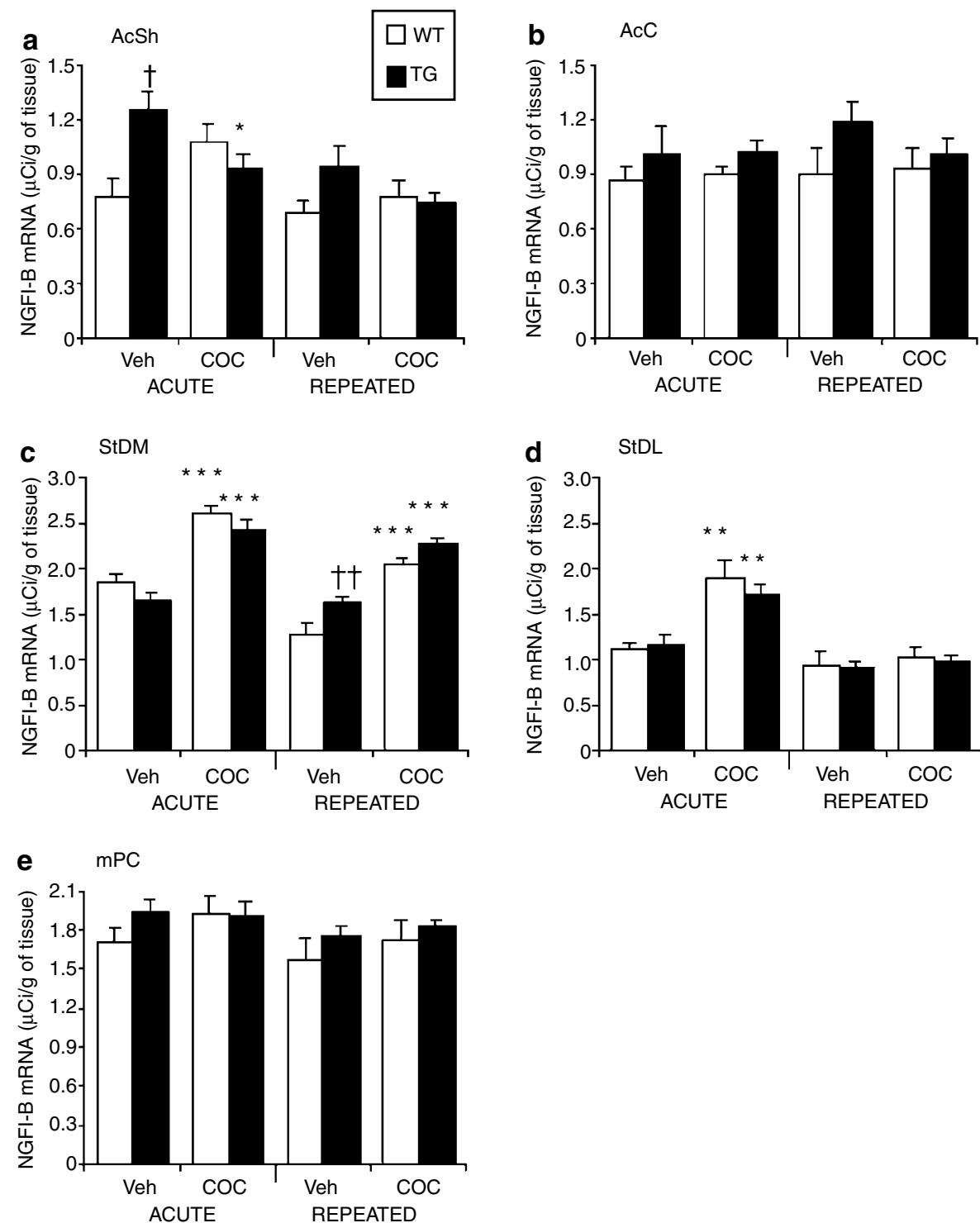

Figure 5 Histograms depicting NGFI-B mRNA levels after acute and repeated COC $(20 \mathrm{mg} / \mathrm{kg})$ administration. In the repeated experiment mice received vehicle or COC following a 5-day COC pretreatment (20 mg/kg). NGFI-B mRNA expression was assessed in the (a) AcSh, (b) AcC, (c) StDM, (d) StDL, and (e) $\mathrm{mPC}$. Results shown represent means $\pm \mathrm{SEM}$. ${ }^{* * *} P<0.00 \mathrm{I}$, ** $P<0.01$, $* P<0.05$ when compared to the same mouse type receiving the vehicle ${ }^{\dagger} P<0.001,{ }^{\dagger} P<0.05$ when compared to WT mice receiving the same treatment. These comparisons were done inside the same treatment, not between means from the acute and the repeated administration.

time course $\left(\mathrm{F}_{3,45}=62.567, P<0.0001\right)$, as well as an interaction between the mouse type and the time course response $\left(\mathrm{F}_{3,45}=9.194, P<0.0001\right)$. The post hoc comparisons indicate a significant increase in COC-induced locomotor response in TG mice for the period $0-30 \mathrm{~min}$ when compared to WT $(P<0.005)$ (Figure $6 \mathrm{c})$. The fourth (not shown), the fifth, and the last COC injections gave rise to identical time course responses between mouse types (Figure $6 \mathrm{~d}$ and e), although the ANOVA for repeated measure indicates a nonsignificant interaction between factors $\left(\mathrm{F}_{3,18}=2.690, P<0.0771\right)$ on the last COC injection because of TG mice-increased basal activity (Figure 6e). Injection of the vehicle on the last day of the treatment produced an increase in locomotor response in both mouse types $\left(F_{3,18}=10.202, P<0.005\right)$ (Figure $\left.6 f\right)$. This effect was, however, stronger in TG animals $\left(\mathrm{F}_{1,6}=6.449, P<0.05\right)$. Once again we must take into account TG mice-increased basal activity $(P=0.0126)$.

\section{DISCUSSION}

This study shows that chronic alteration of the HPA axis can modulate the effect of an acute COC administration on the induction of transcription factors c-fos and NGFI-B in target structures of DA pathways. These changes at the molecular levels are paralleled by changes at the behavioral level. Our results also demonstrate that repeated COC administration can eliminate the differences between TG 

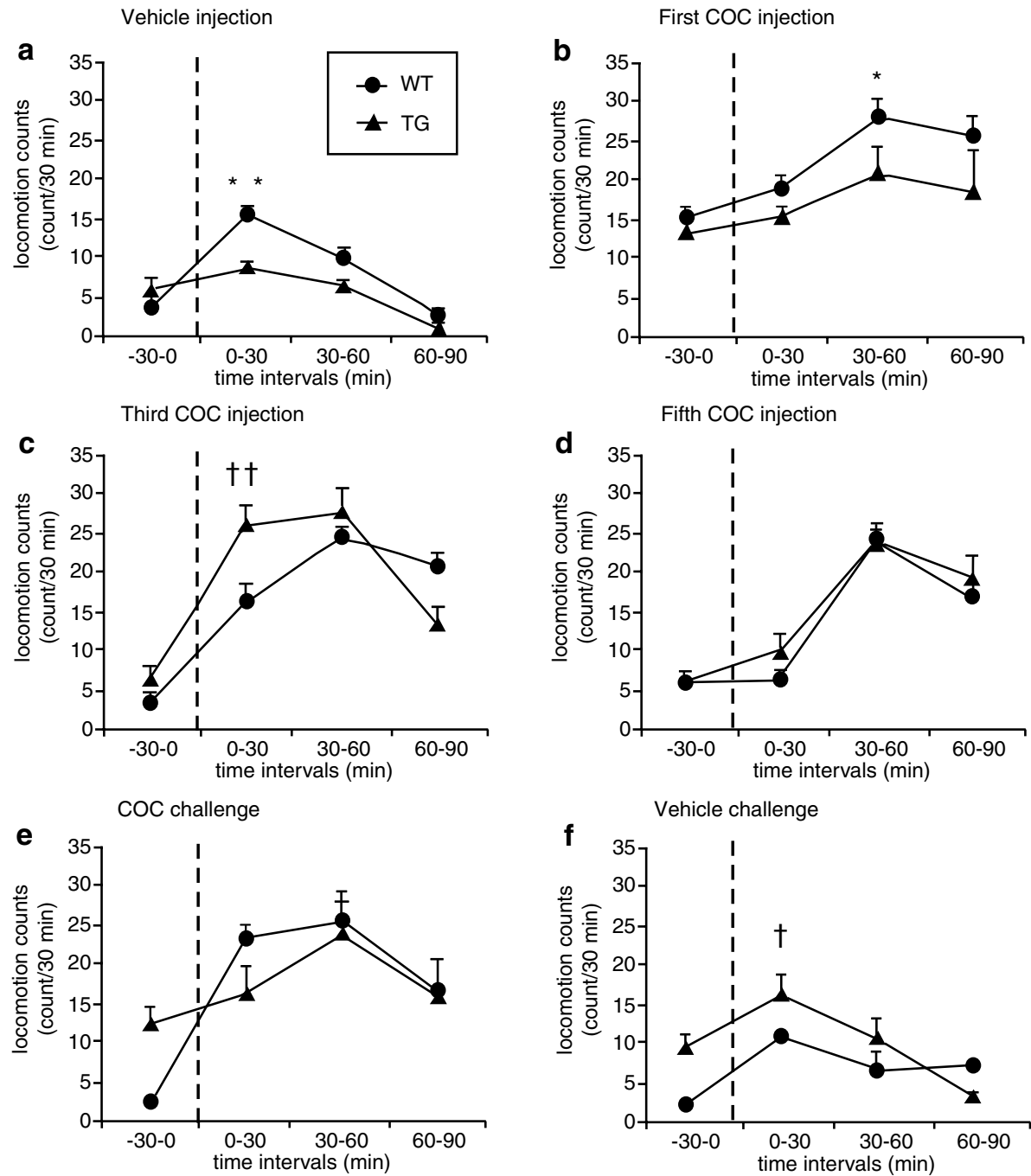

Figure 6 Line charts showing the time course of the locomotor response on different days during the repeated COC experiment: on the day prior to the beginning of the COC treatment, following the injection of the vehicle (a), on the first COC administration day (b), on the third COC administration day (c), on the fifth COC administration day (d) and on day I0, following the COC (e) or vehicle (f) challenge. Dashed lines correspond to the time of the injection. Results shown represent means $\pm \mathrm{SEM}$. $* * P<0.01$, $* P<0.05$ when WT mice present higher locomotor response than TG for the corresponding 30-min period. ${ }^{\dagger \dagger} \mathrm{P}<0.01{ }^{\dagger} \mathrm{P}<0.05$ when TG mice present higher locomotor response than WT for the corresponding 30-min period.

and WT mice suggesting that repeated COC might have a greater impact in TG mice underexpressing GRs.

\section{Modulation of c-fos Expression in TG Mice Following Acute COC Injection}

In WT animals, all target structures of DA pathways displayed important increases in c-fos mRNA levels following both acute $\mathrm{COC}$ injection and repeated COC treatment. However, in mice with impaired GR function, acute COC administration had no or reduced effect on c-fos expression in both the nucleus accumbens and the striatum. In accordance with our results, it has been recently observed that adrenalectomy in rats reduces basal DA extracellular level and decreases COC-induced elevation of Fos-like proteins and extracellular DA in the AcSh (Barrot et al, 2000). Since our mice underexpress GR, some could argue that DA elevation in response to COC was also blunted in TG mice, explaining the smaller c-fos increase reported here. Although the hypothesis of a hypoactive DA function would corroborate our acute data, it would be difficult to reconcile with previous studies done in these mice. Effectively, TG mice underexpressing GRs have higher basal DA synthesis levels (Cyr et al, 2001) and morphineinduced DA release is increased in the nucleus accumbens (Sillaber et al, 1998). Moreover, an increased amphetamineinduced locomotor response has been observed in these TG mice (Cyr et al, 2001). One explanation for the discrepancy between those results and both our behavioral and neurochemical data may stem from an alteration of DA reuptake reported in these TG mice. Cyr et al (2001) have observed lowered levels of DA transporter (DAT) binding sites in the striatum of these TG mice without any change in DAT mRNA levels in the substantia nigra pars compacta. 
Whereas amphetamine elevates extracellular DA levels by acting both on its reuptake and its release (Sulzer and Rayport, 1990; Sulzer et al, 1993), COC rather acts solely by the former mechanism (Ritz et al, 1990a,b). Since c-fos induction after COC administration mostly depends on $\mathrm{D}_{1}$ receptor stimulation (Drago et al, 1996; Das et al, 1997), DAT decrease levels in TG mice should then result in a decreased COC effect on $D_{1}$ receptor. A reduced effect of COC on DA levels in the striatum and the nucleus accumbens could also explain its blunted effect on locomotor response in TG mice. Accordingly, it has been shown that glucocorticoid suppression can also decrease DAT binding in the AcSh (Sarnyai et al, 1998). This hypothesis is supported by the fact that, amongst all DA target structures investigated in the present study, only the mPC was not influenced by the GR knockdown with regard to COC-induced c-fos expression. It has been shown previously that COC increases extracellular DA in the mPC mainly through its action on NA transporter (Tanda et al, 1997; Yamamoto and Novotney, 1998). This particular mechanism of action of COC in the $\mathrm{mPC}$ might explain the absence of difference between mouse strains in this brain region. Together, these results suggest that alteration of HPA functioning may result in an imbalance between DA reuptake in different parts of the brain, which could have an impact on $\mathrm{COC}$ addictive properties.

\section{Modulation of c-fos Expression in TG Mice Following a Repeated COC Treatment}

An interesting finding of our study is that the repeated COC pretreatment potentiated the effect of the $\mathrm{COC}$ challenge on c-fos expression. Although this effect appears to occur in both mouse types in the nucleus accumbens, it was more prominent in TG animals since it abolished differences in cfos expression observed between mouse strains following acute $\mathrm{COC}$ administration. Repeated COC treatment also wipes out behavioral differences between mouse strains observed on the first COC administration. Not only COC pretreatment does potentiate the effect of a subsequent COC challenge, but it also potentiates the effect of the vehicle injection on $\mathrm{c}-$ fos induction in the $\mathrm{mPC}$. Moreover, it produced a COC-conditioned hyperactivity in TG animals, as shown when comparing the effect of the vehicle injection before and after the COC treatment. COC-conditioned hyperactivity is also suggested by the increase in TG mice activity during the $-30-0 \mathrm{~min}$ period on the last treatment day. The formation of Pavlovian conditioning is thus likely to have occurred by the association of neutral stimuli, such as the presence of the experimenter and the injection, and the unconditional rewarding effect of COC. Other studies have also reported a correspondence between COC-conditioned hyperactivity and enhanced Fos expression within the prefrontal cortex and the nucleus accumbens (Franklin and Druhan, 2000; Neisewander et al, 2000). Such observations may underlie the implication of those structures in the development of incentive motivation towards COC and other drugs of abuse.

The restoration of COC-induced c-fos expression noted here could result from COC's own pharmacological properties. In addition to its DA reuptake blocking properties, COC shares with antidepressants the capacity to increase serotonin and noradrenaline levels at the synapse (Chen and Reith, 1994; Andrews and Lucki, 2001). The TG mouse model used in the present study faithfully reproduce many of the neuroendocrinological changes that are known to accompany depression (Beaulieu et al, 1994). Interestingly, treatment with the antidepressant moclobemide for 8 weeks normalizes both basal corticosterone and serotonin increases noted in TG mice underexpressing GR and it brings to control levels the exaggerated increase of DA and 5-HT measured in these TG mice following morphine administration (Sillaber et al, 1998). Chronic treatment with another antidepressant, amitriptyline, was also successful in correcting the decreased DAT levels in the same TG mice (Cyr et al, 2001). Thus, the capacity of the repeated COC treatment to restore c-fos induction in striatum and the nucleus accumbens in the present study may stem from its concomitant action on 5-HT and DA systems.

\section{COC-Induced NGFI-B Expression in TG Mice}

NGFI-B belongs to the nuclear receptor family of transcription factors and is closely associated with DA systems in the brain. Its mRNA level in the brain is modulated by various treatments interacting with DA neurotransmission (Gervais et al, 1999; Tremblay et al, 1999; Beaudry et al, 2000; Werme et al, 2000b; Langlois et al, 2001). Previous data in the literature indicate that its expression is increased by acute and chronic morphine and $\mathrm{COC}$ administration in rats although the effects are different in Lewis and Fisher rat strains (Werme et al, 2000a). In accordance with these results, we found that acute and chronic COC administration increase NGFI-B mRNA expression in the striatum of WT mice. However, TG mice had significantly higher basal NGFI-B levels in the AcSh compared to WT and surprisingly, acute COC administration decreased NGFI-B mRNA expression in this subdivision of the nucleus accumbens, an effect of COC opposed to the one observed in WT. This particular NGFI-B induction pattern suggests important alterations of DA function in the AcSh. Giving its important role in COC addiction, changes in AcSh plasticity could explain TG mice-increased behavioral sensitivity towards repeated COC injection.

The exact role of NGFI-B in target structures of the DA systems is not yet unraveled. We have previously shown that interaction between 5-HTergic and DAergic drugs can lead to different pattern of NGFI-B expression (Gervais et $a l, 1999)$. Indeed $\mathrm{D}_{1}, \mathrm{D}_{2}$, or $5-\mathrm{HT}_{1 \mathrm{~A}}$ receptor agonists administered individually decrease NGFI-B expression, whereas the concomitant administration of $\mathrm{D}_{1}$ and $5-\mathrm{HT}_{1 \mathrm{~A}}$ agonist increases NGFI-B mRNA levels in the striatum. In fact, complex interactions between DA and 5-HT could take place in TG mice underexpressing GR and may be responsible for the basal upregulation of NGFI-B in the AcSh, as well as for the opposite effect of COC on its regulation. Using microdialysis, Sillaber et al (1998) reported enhanced basal 5-HT levels in the nucleus accumbens of this TG mice strain compared to WT mice. We could hypothesize that NGFI-B mRNA elevation in the nucleus accumbens represents a neuroadaptative mechanism occurring in response to an altered 5-HTergic tone in TG animals. 
Behavioral Sensitization Following Repeated COC Administration

According to the behavioral sensitization paradigm (Wise and Bozarth, 1987), the enhanced locomotor response induced by the repeated administration of an addictive drug reflects neuronal adaptation in brain circuit mediating its rewarding effects. In the present study, a clear behavioral sensitization was not shown in WT animals and was only apparent in TG from days 1 to 3 , after which the increase in locomotor response stayed relatively stable. This ceiling effect could in part be because of the dose used and the fact that $\mathrm{COC}$ was administered in the animal home cages. It has been shown that COC at a dose of $10-20 \mathrm{mg} / \mathrm{kg}$ dose would be inclined to give rise to stereotyped behaviors (Hiroi et al, 1997). Such behaviors, like sniffing and rearing, would have been difficult to detect with the telemetric system used. Another explanation for the lack of behavioral sensitization in WT animals could be related to the paradigm of behavioral recording employed in this study. There is some lines of evidence in the literature suggesting that behavioral sensitization is context-dependent (Badiani et al, 1995). As mentioned in the methodology, our animals were recorded and injected in their home cage throughout the entire COC repeated treatment. This particular testing paradigm restricts COC-related cue diversity to the presence of the experimenter and the act of injection. Nevertheless, TG mice displayed behavioral sensitization and COC-conditioned hyperactivity, suggesting a decreased threshold for behavioral sensitization in TG mice bearing an altered HPA axis.

Many lines of evidence argue for a role of stress and glucocorticoid in the attribution of an increased sensitivity towards the effects of drugs of abuse. Like high-responder rats (Piazza et al, 1989), mice underexpressing GR display higher locomotive activity when placed into a novel environment (Beaulieu et al, 1994). The intensity of the locomotive response produced by a novel environment predicts the behavioral response towards addictive substances. Accordingly, high-responder rats will display higher locomotive response following the administration of amphetamine and COC (Piazza et al, 1989; Hooks et al, 1991). Kabbaj et al (2000) have shown that high-responder rats present lower GR mRNA levels in the hippocampus. This decrease in GR mRNA was proposed to be responsible for their carefree-like behavior while exploring an unfamiliar environment since GR in the hippocampus plays a major role in the regulation of the stress response (Sapolsky et al, 1990). Interestingly, our TG mice underexpressing GR also present deficiency in their evaluation of dangerous environments. Indeed, TG mice spend more time than WT in the open arm of the elevated plus maze (Rochford et al, 1997; Strohle et al, 1998). According to these studies, we also reported here a blunted effect of the vehicle injection on TG mice locomotor response, whereas it produced a normal stress-induced locomotor activation in WT. This observation shows that TG mice do not respond properly to stressful events, further confirming their altered HPA axis state and the implication of such disturbance in COC addiction.

In summary, our results obtained with TG mice underexpressing GR showed that alteration of the HPA axis function can modulate acute COC-induced c-fos and NGFI-
B expression in brain structures thought to mediate the rewarding effects of drugs of abuse. An increased basal NGFI-B expression in the AcSh also suggests particular neuronal adaptations induced by GR knockdown in this structure. Finally, we showed that repeated COC administration could potentiate both c-fos induction and COCinduced locomotor response in TG mice so to abolish the differences initially noted between TG and WT mice. Despite this apparent similitude between mouse strains following repeated COC treatment, TG mice were the only ones to display COC-conditioned hyperactivity on the challenge day. Taken together, these observations emphasize the role of the HPA axis in COC addictive properties.

\section{REFERENCES}

Andrews CM, Lucki I (2001). Effects of cocaine on extracellular dopamine and serotonin levels in the nucleus accumbens. Psychopharmacology 155: 221-229.

Badiani A, Browman KE, Robinson TE (1995). Influence of novel versus home environments on sensitization to the psychomotor stimulant effects of cocaine and amphetamine. Brain Res 674: 291-298.

Barden N, Stec IS, Montkowski A, Holsboer F, Reul JM (1997). Endocrine profile and neuroendocrine challenge tests in transgenic mice expressing antisense RNA against the glucocorticoid receptor. Neuroendocrinology 66: 212-220.

Barrot M, Marinelli M, Abrous DN, Rouge-Pont F, Le Moal M, Piazza PV (2000). The dopaminergic hyper-responsiveness of the shell of the nucleus accumbens is hormone-dependent. Eur J Neurosci 12: 973-979.

Beaudry G, Langlois M-C, Weppe I, Rouillard C, Lévesque D (2000). Contrasting patterns and cellular specificity of transcriptional regulation of the nuclear receptor nerve growth factorinducible B by haloperidol and clozapine in the rat forebrain. $J$ Neurochem 75: 1694-1702.

Beaulieu S, Rousse I, Gratton A, Barden N, Rochford J (1994). Behavioral and endocrine impact of impaired type II glucocorticoid receptor function in a transgenic mouse model. Ann NY Acad Sci 746: 388-391.

Chen N-H, Reith MEA (1994). Effects of locally applied cocaine, lidocaine, and various uptake blockers on monoamine transmission in the ventral tegmental area of freely moving rats: a microdialysis study on monoamine interrelationships. J Neurochem 63: 1701-1713.

Clement JG, Mills P, Brockway B (1989). Use of telemetry to record body temperature and activity in mice. J Parmacol Meth 21: 129140.

Cyr M, Morissette M, Barden N, Beaulieu S, Rochford J, Di Paolo T (2001). Dopaminergic activity in transgenic mice underexpressing glucocorticoid receptors: effect of antidepressants. Neuroscience 102: 151-158.

Das S, Grunert M, Williams L, Vincent SR (1997). NMDA and D1 receptors regulate the phosphorylation of CREB and the induction of c-fos in striatal neurons in primary culture. Synapse 25: $227-233$.

Drago J, Gerfen CR, Westphal H, Steiner H (1996). D1 dopamine receptor-deficient mouse: cocaine-induced regulation of immediate-early gene and substance $\mathrm{P}$ expression in the striatum. Neuroscience 74: 813-823.

Farisse J, Hery F, Barden N, Hery M, Boulenguez P (2000). Central $5-\mathrm{HT}_{1}$ and $5-\mathrm{HT}_{2}$ binding sites in transgenic mice with reduced glucocorticoid receptor number. Brain Res 862: 145153. 
Franklin TR, Druhan JP (2000). Expression of Fos-related antigens in the nucleus accumbens and associated regions following exposure to a cocaine-paired environment. Eur J Neurosci 12: 2097-2106.

Gervais J, Soghomonian JJ, Richard D, Rouillard C (1999). Dopamine and serotonin interactions in the modulation of the expression of the immediate-early transcription factor, nerve growth factor-inducible $\mathrm{B}$, in the striatum. Neuroscience 91: 1045-1054.

Hagerty T, Fernandez E, Lynch K, Wang S-S, Morgan WW, Strong $\mathrm{R}$ (2001a). Interaction of a glucocorticoid-responsive element with regulatory sequences in the promoter region of the mouse tyrosine hydroxylase gene. J Neurochem 78: 1379-1388.

Hagerty T, Morgan WW, Elango N, Strong R (2001b). Identification of a glucocorticoid-responsive element in the promoter region of the mouse tyrosine hydroxylase gene. J Neurochem 76: 825-834.

Haile CN, GrandPre T, Kosten TA (2001). Chronic unpredictable stress, but not chronic predictable stress, enhances the sensitivity to the behavioral effects of cocaine in rats. Psychopharmacology 154: 213-220.

Harfstrand A, Fuxe K, Cintra A, Agnati LF, Zini I, Wikstrom AC et al (1986). Glucocorticoid receptor immunoreactivity in monoaminergic neurons of rat brain. Proc Natl Acad Sci USA 83: 9779-9783.

Hiroi N, Brown JR, Haile CN, Ye H, Greenberg ME, Nestler EJ (1997). FosB mutant mice: loss of chronic cocaine induction of Fos-related proteins and heightened sensitivity to cocaine's psychomotor and rewarding effects. Proc Natl Acad Sci USA 94: 10397-10402.

Hooks MS, Jones GH, Smith AD, Neill DB, Justice JB (1991). Response to novelty predicts the locomotor and nucleus accumbens dopamine response to cocaine. Synapse 9: 121-128.

Hope B, Kosofsky B, Hyman SE, Nestler EJ (1992). Regulation of immediate early gene expression and AP-1 binding in the rat nucleus accumbens by chronic cocaine. Proc Natl Acad Sci USA 89: $5764-5768$.

Hope B, Nye HE, Kelz MB, Self DW, Iadarola MJ, Nakabeppu Y et al (1994). Induction of a long lasting AP-1 complex composed of altered Fos-like proteins in brain by chronic cocaine and other chronic treatments. Neuron 13: 1235-1244.

Hyman SE, Malenka RC (2001). Addiction and the brain: the neurobiology of compulsion and its persistence. Nat Rev Neurosci 2: 695-703.

Kabbaj M, Devine DP, Savage VR, Akil H (2000). Neurobiological correlates of individual differences in novelty-seeking behavior in the rat: differential expression of stress-related molecules. $J$ Neurosci 20: 6983-6988.

Langlois M-C, Beaudry G, Rouillard C, Lévesque D (2001). Impact of neuroleptic administration on coordinate expression of nuclear receptors in the cortex and striatal complex of the rat brain. Neuroscience 106: 117-128.

Linthorst ACE, Flachskamm C, Barden N, Holsboer F, Reul JM (2000). Glucocorticoid receptor impairment alters CNS responses to a psychological stressor: an in vivo microdialysis study in transgenic mice. Eur J Neurosci 12: 283-291.

Neisewander JL, Baker DA, Fuchs RA, Tran-Nguyen LT, Palmer A, Marshall JF (2000). Fos protein expression and cocaine-seeking behavior in rats after exposure to a cocaine self-administration environment. J Neurosci 20: 798-805.

Nestler EJ (2001). Molecular basis of long-term plasticity underlying addiction. Nat Rev Neurosci 2: 119-128.

Partridge B, Schenk S (1999). Context-independent sensitization to the locomotor-activating effects of cocaine. Pharmacol Biochem Behav 63: 543-548.

Pepin MC, Pothier F, Barden N (1992). Impaired type II glucocorticoid-receptor function in mice bearing antisense RNA transgene. Nature 355: 725-728.
Piazza PV, Barrot M, Rougé-Pont F, Marinelli M, Maccari S, Abrous DN et al (1996a). Suppression of glucocorticoid secretion and antipsychotic drugs have similar effects on the mesolimbic dopaminergic transmission. Proc Natl Acad Sci USA 93: $15445-15450$.

Piazza PV, Rougé-Pont F, Deroche V, Maccari S, Simon H, Le Moal M (1996b). Glucocorticoids have state-dependent stimulant effects on the mesencephalic dopaminergic transmission. Proc Natl Acad Sci USA 93: 8716-8720.

Piazza PV, Deminiere JM, Le Moal M, Simon H (1989). Factors that predict individual vulnerability to amphetamine self-administration. Science 245: 1511-1513.

Piazza PV, Le Moal M (1998). The role of stress in drug selfadministration. Trends Pharmacol Sci 19: 67-74.

Ritz MC, Boja JW, Grigoriadis D, Zaczek R, Carroll FI, Lewis AH et al (1990a). [ ${ }^{3} \mathrm{H}$ ]WIN 35,065-2: a ligand for cocaine receptors in striatum. J Neurochem 55: 1556-1562.

Ritz MC, Cone EJ, Kuhar MJ (1990b). Cocaine inhibition of ligand binding at dopamine, norepinephrine and serotonin transporters: a structure-activity study. Life Sci 46: 635-645.

Rochford J, Beaulieu S, Rousse I, Glowa JR, Barden N (1997). Behavioral reactivity to aversive stimuli in a transgenic mouse model of impaired glucocorticoid (type II) receptor function: effects of diazepam and FG-7142. Psychopharmacology 132: $145-152$.

Sapolsky RM, Armanini MP, Packan DR, Sutton SW, Plotsky PM (1990). Glucocorticoid feedback inhibition of adrenocorticotropic hormone secretagogue release. Relationship to corticosteroid receptor occupancy in various limbic sites. Neuroendocrinology 51: $328-336$

Sarnyai Z, McKittrick CR, McEwen BS, Kreek MJ (1998). Selective regulation of dopamine transporter binding in the shell of the nucleus accumbens by adrenalectomy and corticosteronereplacement. Synapse 30: 334-337.

Shaham Y, Erb S, Stewart J (2000). Stress-induced relapse to heroin and cocaine seeking in rats: a review. Brain Res Rev 33: 13-33.

Sillaber I, Montkowski A, Landgraf R, Barden N, Holsboer F, Spanagel R (1998). Enhanced morphine-induced behavioural effects and dopamine release in the nucleus accumbens in a transgenic mouse model of impaired glucocorticoid (type II) receptor function: influence of long-term treatment with the antidepressant moclobemide. Neuroscience 85: 415-425.

Spanagel B, Stohr T, Barden N, Holsboer F (1996). Morphineinduced locomotor and neurochemical stimulation is enhanced in transgenic mice with impaired glucocorticoid receptor function. J Neuroendocrinol 8: 93-97.

Stec I, Barden N, Reul JM, Holsboer F (1994). Dexamethasone nonsuppression in transgenic mice expressing antisense RNA to the glucocorticoid receptor. J Psychiatr Res 28: 1-5.

Strohle A, Poettig M, Barden N, Holsboer F, Montkowski A (1998). Age- and stimulus-dependent changes in anxiety-related behaviour of transgenic mice with GR dysfunction. Neuroreport 9: 2099-2102.

Sulzer D, Maidment NT, Rayport S (1993). Amphetamine and other weak bases act to promote reverse transport of dopamine in ventral midbrain neurons. J Neurochem 60: 527-535.

Sulzer D, Rayport S (1990). Amphetamine and other psychostimulants reduce $\mathrm{pH}$ gradients in midbrain dopaminergic neurons and chromaffin granules: a mechanism of action. Neuron 5: 797808.

Tanda G, Pontieri FE, Frau R, Di Chiara G (1997). Contribution of blockade of the noradrenaline carrier to the increase of extracellular dopamine in the rat prefrontal cortex by amphetamine and cocaine. Eur J Neurosci 9: 2077-2085. 
Tremblay M, Rouillard C, Lévesque D (1999). Dopamine $\mathrm{D}_{3}$ receptor antisense administration reduces basal c-fos and NGFI-B mRNA levels in the rat forebrain. Synapse 32: 51-57.

Werme M, Olson L, Brene S (2000a). NGFI-B and Nor-1 mRNAs are upregulated in brain reward pathways by drugs of abuse: different effects in fischer and lewis rats. Mol Brain Res 76: 18-24.

Werme M, Ringholm A, Olson L, Brene S (2000b). Defferential patterns of induction of NGFI-B, Nor-1 and c-fos mRNAs in striatal subregions by haloperidol and clozapine. Brain Res 863: 112-119.
Wise RA, Bozarth MA (1987). A psychomotor stimulant theory of addiction. Psychol Rev 94: 469-492.

Yamamoto BK, Novotney S (1998). Regulation of extracellular dopamine by the norepinephrine transporter. J Neurochem 71: 274-280.

Young ST, Porrino LJ, Iadarola MJ (1991). Cocaine induces striatal c-fos -immunoreactive proteins via dopaminergic D-1 receptors. Proc Natl Acad Sci USA 88: 1291-1295.

Zetterström RH, Williams R, Perlmann T, Olson L (1996). Cellular expression of the immediate early transcription factors Nurr1 and NGFI-B suggests a gene regulatory role in several brain regions including the nigrostriatal dopamine system. Mol Brain Res 41: 111-120. 